\title{
KETIDAKSESUAIAN PRODUK ELEKTRONIKA SETERIKA LISTRIK, POMPA AIR DAN TV TABUNG/CRT TERHADAP STANDAR NASIONAL INDONESIA YANG DIBERLAKUKAN SECARA WAJIB
}

\author{
NON-CONFORMITY OF ELECTRONIC PRODUCTS ELECTRIC IRONS, \\ WATER PUMPS, CRT TELEVISIONS TO INDONESIAN NATIONAL STANDARD \\ MANDATORY
}

\section{Susanto Sigit Rahardi}

Balai Besar Bahan dan Barang Teknik (B4T), Jalan Sangkuriang No.14 Bandung

Diterima: 23 Oktober 2012 Direvisi: 21 November 2012 Disetujui: 21 Desember 2012

\begin{abstract}
ABSTRAK
Pemberlakuan regulasi SNI wajib terhadap produk elektronika seterika listrik, pompa air dan TV tabung telah dilaksanakan sejak tahun 2010. Beberapa ketidaksesuaian terhadap standar nasional didapati pada hasil pengujian yang dilakukan laboratorium di Balai Besar Bahan dan Barang Teknik (B4T). Ketidaksesuaian tersebut dapat diatasi pabrikan dengan baik.
\end{abstract}

Kata kunci: Kesesuaian, SNI, Keselamatan, Seterika listrik, pompa air, TV Tabung/CRT

\section{ABSTRACT}

Implementation of regulation SNI mandatory of electric irons, water pumps, and CRT televisions has been conducted since 2010. Non-conformities have been found at results of testing by laboratory at Center For Metrial And Technical Product (B4T). These non-conformities have been handled successfully by manufacturers.

Keywords: Conformity, SNI, Safety,Electric Iron, Water pump, CRT Television.

\section{PENDAHULUAN}

Untuk mendukung pemerintah dalam penerapan Kebijakan Industri Nasional dan tuntutan masyarakat dalam penerapan standardisasi untuk produk-produk elektronika, Balai Besar Bahan dan Barang Teknik (B4T) melaksanakan pengujian sesuai dengan Standar Nasional Indonesia (SNI) yang berkaitan. Kegiatan pengujian ini dilaksanakan di laboratorium B4T di bawah Seksi Pengujian, Bidang Standardisasi. Pelaksanaan ini adalah penterjemahan dari Peraturan Menteri Perindustrian nomor 84 / M-IND / PER / 8 / 2010 mengenai Pemberlakuan Standar Nasional Indonesia Terhadap 3 (tiga) Produk Industri Elektronika [4], dengan harapan untuk meningkatkan daya saing industri elektronika nasional, menjamin mutu industri, melindungi konsumen terhadap mutu produk, dan menciptakan iklim persaingan usaha yang sehat dan adil.

Peraturan Menteri Perindustrian ini selanjutnya diperinci dengan penunjukan Lembaga Penilaian Kesesuaian pada Peraturan Menteri Perindustrian nomor 109 / M-IND / PER / 10 / 2010, tentang Penunjukan Lembaga Penilaian Kesesuaian Dalam Rangka Pemberlakuan Dan Pengawasan Standar Nasional Indonesia (SNI) [6] yang didalamnya menyatakan bahwa Balai Besar Bahan dan Barang Teknik (B4T) ditunjuk sebagai laboratorium penguji produk elektronika dengan ruang lingkup produk adalah seterika listrik, pompa air, dan TV tabung. Untuk memperjelas pelaksanaan, ditetapkanlah Peraturan Direktur Jenderal Industri Alat Transportasi dan Telematika, Kementerian Perindustrian Republik Indonesia, Nomor 28 / IATT / PER / 9 / 2010 tentang Petunjuk Teknis Pelaksanaan Penerapan Standar Nasional Indonesia Terhadap 
3 (tiga) Produk Industri Elektronika [5] Kementerian Perindustrian Republik Indonesia, Nomor 14 / IUBTT / PER / 3 / 2012, tentang Perubahan Atas Peraturan Direktur Jenderal Industri Alat Transportasi Dan Telematika Nomor 28 / IATT / PER / 8 / 2010 Tentang Petunjuk Teknis Pelaksanaan Penerapan Standar Nasional Indonesia Terhadap 3 (tiga) Produk Industri Elektronika Secara Wajib [8].

Pada pelaksanaanya, didapatkan beberapa ketidaksesuaian terhadap SNI yang diwajibkan. Ketidaksesuaian ini mengindikasikan bahwa mutu produk elektronika tersebut tidak memenuhi SNI dan menunjukkan resiko keselamatan yang tidak dapat diterima. Untuk itu, pabrikan perlu memperbaiki desain produknya sehingga mutu produk memenuhi persyaratan SNI yang berkaitan sehingga mereduksi resiko keselamatan pada pengguna.

Standar untuk produk piranti listrik rumah tangga terdiri dari dua bagian, bagian 1 adalah persyaratan umum dan bagian 2 adalah persyaratan yang lebih khusus bagi produknya. Kedua bagian standar ini harus digunakan secara bersamaan. Pompa air misalnya menggunakan SNI 04-6292.1-2003. Piranti listrik rumah tangga dan sejenisnya Keselamatan - Bagian 1: Persyaratan umum [1] dan SNI 04-6292.2.41-2003(1). Piranti listrik rumah tangga dan sejenisnya - Keselamatan Bagian 2 - 41: Persyaratan khusus untuk pompa [2]. Lain halnya dengan TV tabung / CRT, produk ini menggunakan satu standar saja yaitu SNI 04-6253-2003.Peralatan audio, video dan elektronika sejenis - Persyaratan keselamatan [3].

Kajian atas hasil uji produk elektronika tersebut sejak awal pemberlakuan SNI wajib perlu dilakukan khususnya mengenai ketidaksesuaian apa saja yang muncul pada hasil-hasil pengujian ketiga produk elektronika yang telah wajib SNI tersebut, sejauh apa ketidaksesuaian itu terhadap resiko keselamatan pengguna, bagaimana tanggapan industri dalam memperbaiki mutu desain produk tersebut.

\section{Ketidaksesuaian produk - produk Seterika Listrik terhadap SNI}

Berdasarkan Laporan Hasil Uji produk seterika listrik tahun 2011 sampai 2012, terdapat ketidaksesuaian antara lain mengenai penandaan, persyaratan konstruksi dan komponen. Beberapa Laporan Hasil Uji yang diamati adalah contoh-contoh yang diuji sebagai persyaratan SPPT SNI. Namun demikian, untuk mengetahui dampak penerapan SNI wajib, beberapa Laporan Hasil Uji contoh dalam rangka uji desain juga diamati.

Ketidasesuaian dalam penandaan terdapat pada produk berupa penggunaan bahasa selain Bahasa Indonesia dan juga penandaan suplai pengenal yang belum sesuai dengan SNI. Ketidaksesuaian ini dapat dengan mudah diatasi pabrikan.

Ketidaksesuaian pada konstruksi terletak pada desain tombol atau pengatur yang dapat dengan mudah dicabut oleh pengguna sehingga membahayakan pengguna dari resiko kejutan listrik. Selain itu, terminal listrik dan proteksi pentanahan yang belum sesuai dengan SNI. Beberapa kasus, produk seterika listrik tidak dilengkapi dengan proteksi pentanahan.

Ketidasesuaian komponen adalah pada beberapa produk tidak dilengkapi dengan thermal protector sehingga pada uji abnormal suhu tidak terbatasi sehingga dapat menimbulkan resiko terbakar. Kompnen lain yang penting adalah senur luar yang telah ditetapkan berdasarkan regulasi bahwa jenis senur luar yang digunakan adalah senur beranyam dan bersertifikat SNI. Sebelum SNI wajib, produsen belum menggunakan jenis senur ini. Namun, dengan berlakunya SNI wajib, semua produsen seterika listrik menggunakan jenis senur beranyam. Pada perkembangannya, ketidaksesuaian tidak lagi ditemukan dalam produk-produk yang sudah pernah diuji.

\section{Ketidaksesuaian produk - produk Pompa Air terhadap SNI}

Berdasarkan Laporan Hasil Uji pompa air tahun 2011 sampai 2012, terdapat ketidaksesuaian antara lain mengenai penandaan, konstruksi dan komponen. Tidak semua Laporan Hasil Uji diamati. Pada kajian ini hanya sejumlah 107 Laporan Hasil Uji yang diamati. Sebagian besar produk pompa air adalah produk impor. 


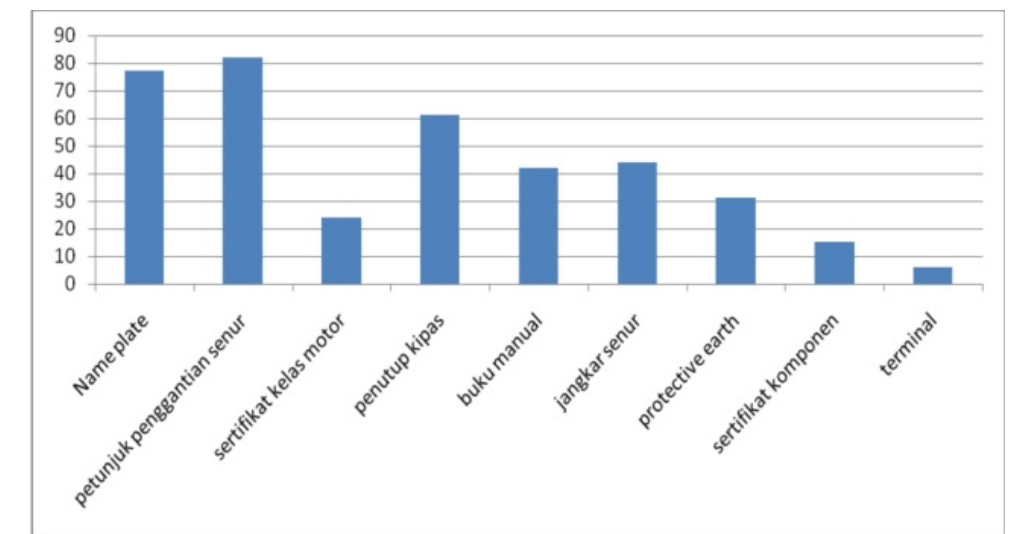

Gambar 1. Jumlah Ketidaksesuaian Produk Pompa Air terhadap SNI

Pada Gambar 1, ketidaksesuaian penandaan, petunjuk penggantian senur, penutup kipas jangkar senur, buku petunjuk penggunaan dan pelindung pembumian adalah kasus yang banyak muncul.

Tanggapan pabrikan atas ketidaksesuaian ini cukup cepat. Pabrikan dapat dengan cepat memperbaiki ketidaksesuaian terhadap SNI terutama produsen pompa air luar negeri. Beberapa kasus produsen dalam negeri sangat lambat dalam mengubah desain agar sesuai dengan SNI. Dalam perkembangannya, hasil surveilance sudah tidak terdapat ketidaksesuaian. Hal ini menandakan bahwa
SNI wajib berdampak efektif bagi perubahan desain agar sesuai dengan SNI terkait.

\section{Ketidaksesuaian produk - produk TV Tabung / CRT terhadap SNI \\ Bedasarkan Laporan Hasil Uji TV tabung tahun 2011 sampai 2012, terdapat ketidaksesuaian antara lain penandaan, konstruksi, komponen dan bahan yang digunakan. Hanya beberapa Laporan Hasil Uji yang diamati, yaitu 60 Laporah Hasil Uji. Ketidaksesuaian berdasarkan ayat pada SNI04- 6253-2003 dapat disajikan pada Gambar 2 berikut:}

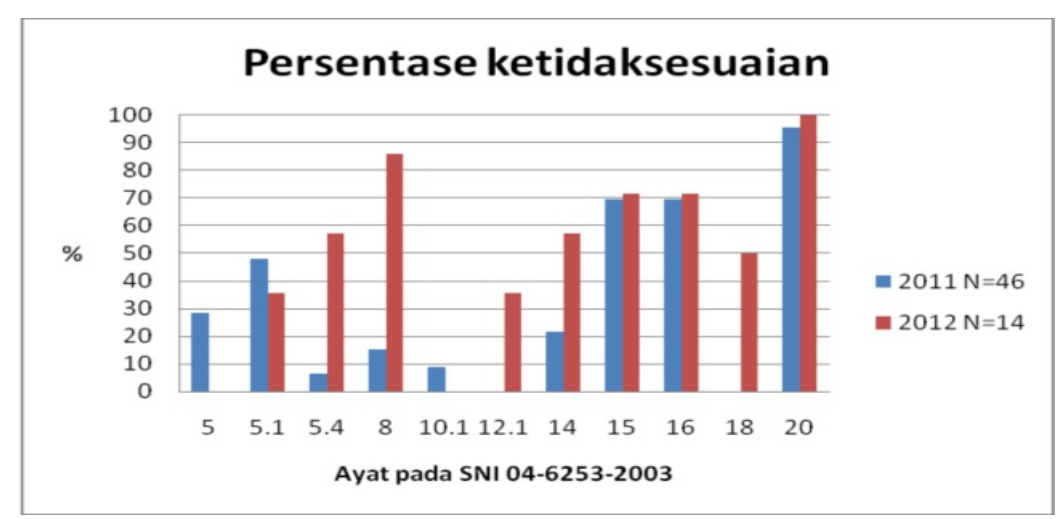

Gambar 2. Ketidaksesuaian Berdasarkan Ayat pada SNI 04-6253-2003

Pada gambar 2, beberapa jenis ketidaksesuaian tahun 2011 tidak lagi ditemukan pada tahun 2012. Ketidaksesuaian pada ayat 18 yaitu persyaratan konstruksi pada tabung gambar muncul pada tahun 2012 dikarenakan adanya produk TV tabung yang menggunakan tabung rekondisi.

Ketidaksesuaian yang mempunyai peluang yang sama pada tahun 2011 dan tahun 2012 adalah bahan tahan api atau V-1 yang merupakan persyaratan SNI untuk produk TV tabung. Solusi yang dipilih pabrikan adalah mengubah bahan yang dipersyaratkan menjadi V-1 atau lebih baik. Solusi lain adalah dengan memberikan jarak yang cukup berdasarkan SNI dari daerah yang berpotensi sebagai sumber api. Mayoritas produsen TV tabung adalah produsen dalam negeri. Produk TV tabung secara teknologi juga sudah dalam taraf matang. Untuk itu, proses perbaikan ketidaksesuaian juga tidak memakan waktu yang lama. Dalam hal ini, produsen mempunyai tanggapan yang tinggi terhadap adanya ketidaksesuaian. 


\section{KESIMPULAN}

Penerapan Standar Nasional Indonesia terhadap tiga produk industri elektronika seterika listrik, pompa air dan TV tabung / CRT telah mampu meningkatkan mutu kesesuaian terhadap standar terkait. Ketidaksesuian terhadap SNI dapat diatasi pabrikan dengan baik.

\section{UCAPAN TERIMA KASIH}

Penulis mengucapkan terima kasih kepada Bapak Budi Susanto selaku Kepala Bidang Standardisasi B4T, Bapak Irwan Inayaturohman, Ibu Sumarni, Ibu Elmi dan Saudara Kamaludin atas kerjasamanya sehingga tersusunnya tulisan kajian kondisi industri elektronika. Semoga tulisan ini bermanfaat bagi perkembangan industri elektronika dalam negeri.

\section{DAFTAR PUSTAKA}

[1] SNI 04-6292.1-2003. Piranti listrik rumah tangga dan sejenisnya - Keselamatan Bagian 1: Persyaratan umum. Badan Standardisasi Nasional (BSN), Republik Indonesia.

[2] SNI 04-6292.2.41-2003(1). Piranti listrik rumah tangga dan sejenisnya Keselamatan - Bagian 2 - 41: Persyaratan khusus untuk pompa. Badan Standardisasi Nasional (BSN), Republik Indonesia.

[3] SNI 04-6253-2003.Peralatan audio, video dan elektronika sejenis - Persyaratan keselamatan. Badan Standardisasi Nasional (BSN), Republik Indonesia.

[4] Peraturan Menteri Perindustrian Republik Indonesia, Nomor 84 / M-IND / PER / 8 / 2010 tentang Pemberlakuan Standar Nasional Indonesia Terhadap 3 (tiga) Produk Industri Elektronika.

[5] Peraturan Direktur Jenderal Industri Alat Transportasi dan Telematika, Kementerian Perindustrian Republik Indonesia, Nomor 28 / IATT / PER / 9 / 2010 tentang Petunjuk Teknis Pelaksanaan Penerapan Standar Nasional Indonesia Terhadap 3 (tiga) Produk Industri Elektronika.

[6] Peraturan Menteri Perindustrian Republik Indonesia, Nomor 109 / M-IND / PER /
10 / 2010, tentang Penunjukan Lembaga penilai Kesesuaian Dalam Rangka Pemberlakuan Dan Pengawasan Standar Nasional Indonesia (SNI) atas 58 (lima puluh delapan) Produk Industri Secara Wajib.

[7] Peraturan Menteri Peridustrian Republik Indonesia, Nomor 42 / M-IND / PER / 3 / 2010, tentang Pemberlakuan Standar Nasional Indonesia Kabel Secara Wajib.

[8] Peraturan Direktur Jenderal Industri Unggulan Berbasis Teknologi Tinggi, Kementerian Perindustrian Republik Indonesia, Nomor 14 / IUBTT / PER / 3 / 2012, tentang Perubahan Atas Peraturan Direktur Jenderal Industri Alat Transportasi Dan Telematika Nomor 28 / IATT / PER / 8 / 2010 Tentang Petunjuk Teknis Pelaksanaan Penerapan Standar Nasional Indonesia Terhadap 3 (tiga) Produk Industri Elektronika Secara Wajib.

[9] Laporan Hasil Uji Produk Seterika Listrik tahun 2011 - 2012. Balai Besar Bahan dan Barang Teknik, Kementerian Perindustrian Republik Indonesia.

[10] Laporan Hasil Uji Produk Pompa air tahun 2011 - 2012. Balai Besar Bahan dan Barang Teknik, Kementerian Perindustrian Republik Indonesia.

[11] Laporan Hasil Uji Produk TV Tabung / CRT tahun 2011 - 2012. Balai Besar Bahan dan Barang Teknik, Kementerian Perindustrian Republik Indonesia. 
Jurnal Teknologi Bahan dan Barang Teknik Vol. 2, No. 2, Desember 2012 : 75 - 84 